\title{
Bimbingan Teknis Olahan Pangan Hewani untuk Meningkatkan Pengetahuan TP PKK Desa Jatinom, Kabupaten Blitar
}

\section{(Technical Asistance about Animal-Based Food Procesing to Increase Knowledge of the TP PKK Jatinom Village, Blitar District)}

\author{
Lestariningsih ${ }^{*}$, Peni Nohantiya ${ }^{2}$ \\ ${ }^{1}$ Prodi Peternakan, Fakultas Ilmu Eksakta, Universitas Nahdlatul Ulama Blitar, \\ Jalan Masjid 22, Kota Blitar, Jawa Timur 66117. \\ 2 Prodi Pendidikan Olahraga, Fakultas Ilmu Pendidikan dan Sosial, Universitas Nahdlatul Ulama Blitar, \\ Jalan Masjid 22, Kota Blitar, Jawa Timur 66117. \\ *Penulis Korespondensi: tariunu@gmail.com \\ Diterima Maret 2018/Disetujui Desember 2018
}

\begin{abstract}
ABSTRAK
Kegiatan pengabdian masyarakat ini bertujuan untuk meningkatkan pengetahuan mitra dalam memanfaatkan potensi pangan hewani di desa mitra. Hal ini didasarkan pada permasalahan mitra, yaitu kurang memahami olahan asal pangan hewani sedangkan Desa Jatinom memiliki potensi pangan hewani. Masyarakat Jatinom memanfaatkan pangan hewani sebatas skala rumah tangga untuk lauk pauk. Sedangkan, banyak penduduk yang berprofesi sebagai peternak dan buruh ternak serta mereka sangat berkesempatan untuk mendapatkan bahan baku produk asal hewan dengan harga yang relatif lebih murah. Jika bahan baku pangan ternak tersebut diolah lebih baik maka nilai jualnya akan lebih tinggi. Melalui program PKM ini, tim pelaksana pengabdian kepada masyarakat memberikan solusi padap permasalahan yang dihadapi mitra untuk memelopori gerakan mengolah olahan pangan hewani menjadi pangan yang lebih bernilai ekonomis dengan memberikan bimtek olahan pangan hewani. Target khusus yang ingin dicapai adalah peningkatan pengetahuan mitra dalam mengolah pangan hewani untuk mendapatkan produk hewan yang memiliki nilai ekonomi tinggi. Metode yang digunakan adalah observasi, wawancara, dan menjalin kerja sama dengan mitra untuk menyelesaikan permasalahan sesuai dengan kesepakatan bersama dengan meluangkan waktu 12 jam/minggu selama pelaksanaan program PKM, yaitu pada bulan Desember 2017, menyiapkan rencana program kegiatan pengabdian kepada masyarakat, misalnya memberikan bimbingan teknis kepada mitra tentang pentingnya olahan pangan hewani untuk meningkatkan pengetahuan Tim Pengerak PKK Desa Jatinom Kabupaten Blitar. Hasil pengabdian yang dilakukan menunjukkan bahwa bimbingan teknis olahan pangan asal hewani dapat meningkatkan pengetahuan ibu PKK Desa Jatinom, Kecamatan Kanigoro, Kabupaten Blitar. Pengabdian ini perlu ditindaklanjuti dengan adanya pelatihan olahan hasil ternak secara langsung.
\end{abstract}

Kata kunci: pengabdian, pengetahuan, PKK Jatinom

\begin{abstract}
The purpose of this dedication to miter increase knowledge on animal food potential benefited in the miter village. That was cause the problem of miner less understand technology to process animal food. Besides, Jatinom village had animal food pontential. Jatinom society used animal food such as milk and egg only to side dish in their family. Besides, many inhabitant works in the farm of animal as farmer and employees. Therefore, they have opportunity to get animal material product with low prices. When it proceses better so its can get high prices. By of this dedication, official give solution on the miter problem to pioneer movement proceses of animal food had economic value with proceses animal food guidance. Specially target in this dedication, its to increase miter knowledge on animal food proceses to get high prices. The methods used observation, interview, and partnership to finish the problems there with 12 times in the week as long this dedication in December 2017, prepare the planning program such as give guidance about important of animal food process to increase miner knowlegde (TP PKK Jatinom Village). The result of this dedication was guidance animal food process can open knowledge to increase miner productive (TP PKK Jatinom Village, Kanigoro Subdistrict, Blitar District). The dedication need to follow by direct coaching animal food proceses.
\end{abstract}

Keywords: dedication, knowledge, PKK Jatinom 


\section{PENDAHULUAN}

Kegiatan pengabdian kepada masyarakat dengan Program Kemitraan Masyarakat (PKM) ini bermitra dengan Desa Jatinom, Kecamatan Kanigoro, Kabupaten Blitar. Kegiatan pengabdian ini melibatkan organisasi sosial Desa Jatinom sebagai mitra, yaitu Kelompok Tim Pengerak Pemberdayaan Kesejahteraan Keluarga (TP PKK). Berdasarkan hasil observasi diketahui mitra tersebut merupakan salah satu organisasi sosial desa yang berperan dalam lembaga penunjang pemberdayaan kesehatan masyarakat Desa Jatinom. Menurut Sitepu (2016) oganisasi sosial adalah wadah partisipasi masyarakat secara terlembaga. Organisasi sosial merupakan hal yang penting karena semakin tinggi partisipasi masyarakat dalam pembangunan kesejahteraan sosial maka akan semakin sedikit permasalahan yang berkembang.

Secara geografis, Desa Jatinom merupakan wilayah yang terdiri dari dataran rendah dengan ketinggian $180 \mathrm{mdpl}$ dengan luas $22.050 \mathrm{~km}^{2}$. Wilayah tersebut terdiri dari pemukiman penduduk, tanah tegalan, perkebunan, persawahan, dan lahan kering. Letak Desa Jatinom berada di antara beberapa desa yang lain. Adapun batas desa sebelah barat berbatasan dengan Kelurahan Klampok dan sebelah utara berbatasan dengan Kelurahan Karang Tengah, Kecamatan Sanan Wetan, Kota Bitar. Sedangkan, sebelah timur berbatasan dengan Desa Gogodeso dan selatan berbatasan dengan Desa Minggirsari, Kecamatan Kanigoro, Kabupaten Blitar. Jarak antara Desa Jatinom (desa mitra) dengan Kampus Universitas Nahdlatul Ulama (UNU) Blitar 5,4 km dengan jarak tempuh 15 menit.
Letak geografis Desa Jatinom yang strategis dan merupakan jalur penghubung antara Kabupaten Tulungagung, Malang dan Kediri memberikan pengaruh terhadap mata pencaharian penduduknya. Mata pencaharian berdagang memiliki persentase paling besar, diikuti bertani, PNS dan buruh tani (Gambar 1). Selain itu, berdasarkan data dari Dinas Peternakan Kabupaten Blitar setiap harinya dapat menghasilkan 480 ton telur. Desa penghasil telur terbanyak merupakan Desa Jatinom. Selain itu, berdasarkan hasil wawancara dengan kepala desa diketahui bahwa Desa Jatinom memiliki beberapa komoditas ternak di antaranya adalah ayam petelur, ayan pedaging, kambing, puyuh, sapi potong, dan sapi perah. Kepala Desa Jatinom mempunyai kebijakan bahwa sudah tidak diperbolehkan adanya komoditas ternak baru. Hal ini disebabkan Desa Jatinom ingin mengembangkan olahan ternak sehingga menjadi icon desa yang mampu mengolah produk peternakan dari hulu hingga hilir. Optimalisasi pengolahan produk di daerah secara tidak langsung dapat meningkatkan ketahanan pangan nasional (Ariani 2010).

Menurut Kepala Desa Jatinom, semua kebijakan yang telah ditetapkan maka dalam pelaksanaannya selanjutnya dibantu oleh semua elemen masyarakat desa salah satunya organisasi sosial desa dalam hal ini adalah TP PKK. Mitra dalam kelompok TP PKK ini diketuai oleh Ibu Muashomah. Berdasarkan hasil wawancara dengan ketua kelompok TP PKK diketahui bahwa pendidikan kader organisasi tersebut hanya $21,25 \%$ yang lulusan sarjana. Sisanya $78,75 \%$ merupakan lulusan SMA dan SMP. Oleh karena itu, dapat disimpulkan bahwa pendidikannya masih rendah. Berkaitan dengan hal tersebut,

\footnotetext{
Persentase pekerjaan masyarakat Desa Jatinom
}



Sumber: RPJM Desa Jatinom 2014-2019

Gambar 1 Persentase mata pencaharian warga Desa Jatinom Tahun 2016. 
ketua kelompok TP PKK sangat berharap adanya tambahan pengetahuan untuk menunjang kesejahteraan desa salah satunya bidang olahan pangan asal hewan.

Pada umumnya mitra mempunyai permasalahan masih kurangnya pengetahuan terhadap olahan hasil ternak sehingga dalam pemanfaatan produk pangan asal ternak hanya digunakan sebagai lauk pauk sehari-hari. Padahal potensi produk asal hewani cukup besar. Jika potensi ini dikembangkan maka nilai jual dari produk olahan hewani semakin tinggi (Rachman \& Ariani 2008). Oleh karena itu, diperlukan bimbingan teknis terkait dengan olahan pangan hewani untuk meningkatkan pengetahuan dari tim pengerak PKK Desa Jatinom, Kecamatan Kanigoro, Kabupaten Blitar. Berdasarkan permasalahan prioritas yang dialami oleh mitra, maka dibutuhkan program bimbingan teknis untuk tercapainya kemandirian dan kesejahteraan mitra. Bimbingan teknis ini diperlukan untuk meningkatkan kualitas SDM mitra terutama dalam hal mengolah pangan asal hewan. Dengan demikian diharapkan mitra dapat mengetahui, memahami, dan mampu mengaplikasikan olahan pangan asal hewan yang memiliki nilai jual lebih tinggi.

Target luaran yang dicapai untuk mitra adalah terjalinnya kerja sama yang saling menguntungkan dan berkaitan antara kedua belah pihak secara berkelanjutan. Tim pengabdian memberikan sosialisai terkait dengan olahan pangan hewani untuk meningkatkan pengetahuan TP PKK Desa Jatinom, Kecamatan Kanigoro, Kabupaten Blitar. Selain itu, Mitra dapat mengetahui olahan produk pangan asal hewan dan penanganannya serta mampu mensosialisasikan kepada anggota PKK dan anggota dapat mensosialisasikan kepada para ibu rumah tangga. Sosialisasi kepada ibu rumah tangga sangat penting karena keluarga harus mampu menyediakan olahan pangan yang baik untuk mendukung kesehatan keluarga (Siahaan 2017; Azhari et al. 2013). Adapun beberapa olahan asal hewan yang disosialisasikan adalah telur dan susu. Produk asal hewan memerlukan penanganan yang lebih dibandingkan produk lain, hal ini disebabkan oleh produk hewani yang mudah terkontaminasi (Susanto et al. 2018). Suharyanto (2009) menyatakan bahwa telur untuk memperpanjang daya simpannya dan meningkatkan nilai ekonomis dapat diolah menjadi tepung telur, mayones, telur asin, acar telur, dan telur asap sedangkan susu dapat diolah menjadi susu bubuk, yoghurt, susu pasteurisasi, susu UHT, mentega, dan es krim. Oleh karena itu, diperlukan pengabdian bimbingan teknis olahan pangan asal hewani untuk meningkatkan produktivitas TP PKK Desa Jatinom, Kecamatan Kanigoro, Kabupaten Blitar.

\section{METODE PELAKSANAAN KEGIATAN}

\section{Waktu dan Tempat}

Kegiatan pengabdian ini dilaksanakan pada bulan Desember 2017 di Kantor PKK Desa Jatinom, Kecamatan Kanigoro, Kabupaten Blitar.

\section{Partisipan}

Kegiatan pengabdian ini dihadiri oleh TP PKK Desa Jatinom, PKK dan Pengurus Dasawisma Desa Jatinom, Kecamatan Kanigoro, Kabupaten Blitar. Jumlah Partisipan sebanyak 50 orang.

\section{Alat dan Bahan}

Alat dan bahan yang diperlukan dalam kegiatan pengabdian ini adalah LCD, laptop, materi kegiatan bimtek olahan susu, dan telur.

\section{Metode Kegiatan dan Pengumpulan Data}

Adapaun metode pelaksanaan dalam kegiatan ini adalah survei, analisa masalah, bimbingan teknis program, evaluasi, dan pemberian rekomendasi untuk program selanjutnya.

\section{Survei}

Permasalahan mitra yang saat ini telah teridentifikasi adalah kurangnya pengetahuan pada olahan pangan hewani. Akan tetapi, belum diketahui pasti olahan pangan hewani yang diperlukan mitra sehingga diperlukan survei lokasi lebih lanjut dengan memberikan angket kepada mitra. Selain itu, diperlukan wawancara untuk pengalian data lebih lanjut sebelum diadakan sosialisasi.

\section{Analisa Masalah Mitra}

Data yang telah diperoleh selanjutnya dianalisa menggunakan analisa SWOT sehingga diketahui kekuatan, kelemahan, peluang, dan tantangan yang ada dalam mitra. Data yang telah dianalisa diharapkan mampu membantu tim pengabdian dalam menentukan berbagai rangkaian sosialisasi yang diberikan.

\section{Pelaksanaan Program}

Pelaksanaan program dalam pengabdian terdiri dari beberapa tahap di antaranya menentukan tim pelaksanan, merancang program lebih lanjut, dan pelaksanaan program sosialisasi. 


\section{Pembentukan Tim Pelaksana}

Pelaksana program PKM adalah dosen dan mahasiswa peternakan fakultas ilmu eksakta, dosen program studi pendidikan olahraga, fakultas ilmu pendidikan dan sosial, Universitas Nahdatul Ulama Blitar, serta Kelompok TP PKK Desa Jatinom, Kecamatan Kanigoro, Kabupaten Blitar. Pembentukan tim pelaksana dimaksudkan untuk pembagian kerja sehingga pelaksanaan program dapat berjalan sesuai dengan tujuan.

\section{Persiapan Pelaksanaan}

Tahap persiapan pelaksanaan program meliputi rapat koordinasi oleh tim pelaksana, persiapan perijinan dan administrasi lainnya, persiapan alat dan bahan serta persiapan materi sosialisasi.

\section{Pelaksanaan Program}

Program PKM dilaksanakan pada akhir pekan (hari sabtu dan minggu) bulan Desember 2017. Kegiatan yang telah dilaksanakan meliputi bimbingan teknis olahan telur dan susu.

\section{Monitoring dan Evauasi}

Kegitan monitoring dan evaluasi program PKM telah dilaksanakan pada bulan Desember 2017 akhir pekan minggu ke-4. Kegiatan monitoring dan evaluasi merupakan suatu wadah diskusi antara tim pelaksana program dengan mitra sasaran tentang sejauh mana penerimaan materi sosialisasi yang telah dilaksanakan. Hasil monitoring dan evaluasi digunakan sebagai acuhan dalam menentukan pelaksanaan program dan rekomendasi untuk kegiatan selanjutnya.

\section{Lokakarya Hasil}

Lokakarya hasil telah dilaksanakan sesuai dengan jadwal yang ditetapkan. Kegiatan lokakarya hasil melibatkan mitra sasaran dan mengundang stakeholder yang ada di masyarkat setempat.

\section{Pengolahan dan Analisis Data}

Data diolah secara deskripsi dengan justifikasi ahli.

\section{HASIL DAN PEMBAHASAN}

Bimbingan teknis ini dilaksanakan pada Desember 2017 bertempat di Ruang TP PKK Desa Jatinom, Kecamatan Kanigoro, Kabupaten Blitar (Gambar 2). Kegiatan tersebut dihadiri oleh 50 peserta yang terdiri dari pengurus TP PKK, anggota TP PKK, dan Dasawisma. Produk Olahan yang dikenalkan di antaranya adalah produk olahan asal ternak yang terdiri produk utama, yaitu susu dan telur.

\section{Bimbingan Teknis Produk Olahan Susu}

Bimbingan teknis produk olahan susu terdiri dari susu pasteurisasi dan yoghurt. Anita dan Karjadidjaja (2014) menyatakan bahwa susu dan produk hasil olahan susu merupakan pelengkap zat-zat gizi yang baik bagi tubuh manusia. Susu segar sangat mudah didapatkan di Desa Jatinom dan mudah untuk diolah. Tujuan kegiatan ini adalah untuk memberikan wawasan bimtek yang dilaksanakan pada ibu-ibu PKK meliputi pengenalan produk olahan susu dan telur serta cara mengolahnya. Bimtek pertama terkait dengan produk susu, yaitu susu pasteurisasi dan yoghurt. Susu pasteurisasi merupakan susu segar yang dipanaskan dengan menggunakan suhu tertentu. suhu yang terbaik dalam pengolahan susu segar menjadi susu pasteurisasi adalah $65^{\circ} \mathrm{C}$ selama 35 menit (Abubakar et al. 2001). Sedangkan, menurut BSN (1995) menyatakan bahwa susu pasteurisasi merupakan produk susu yang dihasilkan dari susu segar, susu rekonstitusi atau susu rekombinasi yang telah mengalami proses pemanasan pada suhu $63-66^{\circ} \mathrm{C}$ selama minimum 30 menit atau pada pemanasan $72^{\circ} \mathrm{C}$ selama 15 menit kemudian segera didinginkan sampai $10^{\circ} \mathrm{C}$, selanjutnya diperlakukan secara aseptis dan disimpan pada suhu maksimum $4,4^{\circ} \mathrm{C}$. Pemanasan susu dengan menggunakan $60^{\circ} \mathrm{C}$ menurut Kustanti (2012) merupakan pemanasan metode Low Temperature Long Time (LTLT). Perbedaan tinggi rendahnya suhu dalam pasteurisasi berpengaruh pada ketahanan makanan dan minuman yang dipasteurisasi akan tetapi tidak mengubah rasa dari susu.

Bimtek kedua terkait dengan olahan asal susu, yaitu yoghurt. Yoghurt merupakan produk susu

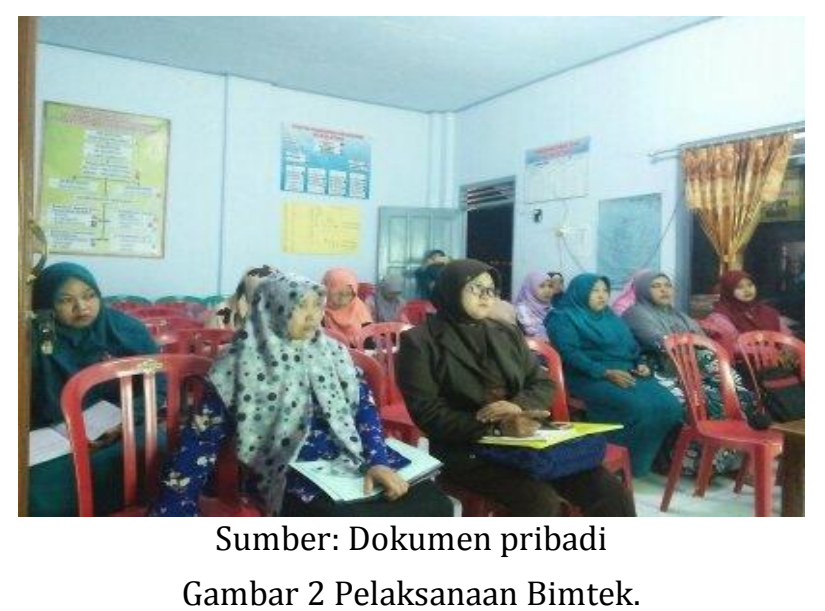


yang banyak digemari. Pengolahan yoghurt dengan membuat susu pasteurisasi, ditambahkan starter dan dilakukan fermentasi. Penyimpanan yoghurt lebih lama daripada susu pasteurisasi. Sirait (1984) menyatakan bahwa yoghurt merupakan minuman tradisional yang bermanfaat bagi orang yang tidak tahan terhadap gula susu (laktose). Hal ini disebabkan proses pembuatan yoghurt dapat menurunkan seperempat kadar gula susu yang ada. Cara pembuatan yoghurt dengan memanaskan susu (pasteurisasi) kemudian didinginkan, dimasukkan starter berupa mikroorganisme dan difermentasi. Dari bimtek produk olahan susu yang terdiri dari pembuatan susu pasteurisasi dan yoghurt mengundang antusias dari peserta bimtek. Banyak tanggapan terkait dengan hal tersebut yang dilatarbelakangi karena ketidaktahuan dalam proses pembuatan susu pasteurisasi dan yoghurt.

\section{Produk Olahan Telur}

Produk olahan telur yang disosialisasikan dalam bimtek adalah telur asin. Telur asin merupakan salah satu telur yang diproduksi oleh bebek. Telur bebek yang diolah menjadi telur asin memiliki daya simpan yang relatif lebih lama. Menurut Winarti (2014), prinsip dari pengawetan telur asin, yaitu untuk mencegah penguapan dan kehilangan karbondioksida dari dalam telur, mencegah pengenceran putih telur dan mencegah masuknya mikroorganisme kedalam telur. Pengawetan dengan telur asin biasa dikenal dengan pengawetan garam. Cara pembuatan telur asin dengan menggunakan cara basah dan kering. Cara basah pada umumnya menggunakan bantuan larutan garam jenuh. Cara ini dilakukan dengan membuat larutan garam yang digunakan untuk merendam telur selama 10-12 hari. Sedangkan cara kering dilakukan dengan menggunakan garam dengan abu (1:2). Hal ini dilaksanakan selama 10 hari. Pembuatan telur asin dapat menggunakan berbagai variasi rasa rempah seperti jahe dan kunyit sebagai salah satu diversifikasi produk telur asin (Mua'addimah et al. 2015; Hakim et al. 2017). Selain itu, hal-hal yang perlu diperhatikan dalam pegolahan telur asin adalah lamanya perendaman dan banyaknya garam yang diberikan (Hastuti 2010).

\section{Pembahasan Peningkatan Pengetahuan Ibu- Ibu PKK Desa Jatinom}

Bimbingan teknis produk olahan susu dan telur yang dilaksanakan di Desa Jatinom kepada ibu-ibu PKK meliputi pengenalan produk dan cara mengolahnya. Untuk melihat hasil peningkatan wawasan dan pengetahuan tentang kedua hasil olahan ternak tersebut dapat diperoleh dari keterangan Ibu-ibu PKK Desa Jatinom. Sebelum adanya bimtek, pengetahuan ibu-ibu dalam mengolah susu dan hasil ternak masih terbatas $(30 \%)$. Susu pada umumnya hanya dikonsumsi dengan cara perebusan atau pemanasan kemudian ditambahkan gula atau kopi. Perebusan susu yang selama ini dilakukan oleh peserta bimtek pada umumnya adalah sebatas merebus secara langsung sampai mendidih sebagaimana dalam perebusan air minum. Dengan adanya bimtek olahan susu pasteurisasi peserta bimtek menjadi tahu cara perebusan susu pasteurisasi dengan baik dan benar. Selain itu, dalam pengolahan telur peserta bimtek selama ini yang dilakukan adalah sebatas mengoreng, merebus, dan memasak sebagai lauk pauk yang sekali saji. Dengan adanya bimtek ini maka peserta menyadari bahwa masih banyak olahan telur yang bisa dilakukan dengan meningkatkan kualitas dari telur, meningkatkan nilai jual telur, dan memperpanjang daya simpan telur. Terkait dengan produk penyimpanan susu dan telur, dengan adanya bimtek ini peserta mengetahui bahwa ada batas dalam penyimpanan produk telur dan susu. Hal ini disebabkan produk peternakan mempunyai nilai protein yang tinggi sehingga mudah terkontaminasi oleh mikroorganisme. Sehingga peserta bimtek dapat menyimpan telur dan susu dengan tempat yang baik dan dalam batas nilai simpan tertentu. Tingkat pengetahuan mitra meningkat $30 \%$ menjadi $60 \%$. Peningkatan pengetahuan tersebut jika ditindaklanjuti dengan aplikasi dan pendampingan maka dalam jangka panjang dapat meningkatkan pendapatan dari kelompok PKK (Tantalu et al. 2017).

\section{SIMPULAN}

Bimbingan teknis olahan produk asal ternak dapat meningkatkan 30\% pengetahuan ibu-ibu PKK Desa Jatinom, Kecamatan Kanigoro, Kabupaten Blitar dari 30\% menjadi 60\%. Program bimbingan teknik ini diharapkan dapat dilanjutkan dengan praktik secara langsung melalui pelatihan pengolahan pangan asal hewani. 


\section{DAFTAR PUSTAKA}

Abubakar, Triyantini, Sunarlim R, Setiyanto H, Nurjannah. 2001. Pengaruh suhu dan waktu pasteurisasi terhadap mutu susu selama penyimpanan. Jurnal Ternak dan Veteriner. 6 (1): 45-50.

Anita S, Karjadidjaja I. 2014. Hubungan pola asupan susu dan hasil olahan susu dengan tinggi badan pada anak kelas 4 SD Bunda Hati Kudus periode Februari 2014. Jurnal Tarumanagara Medical. 1(1): 174-182.

Ariani M. 2010. Analisis konsumsi pangan tingkat masyarakat. Jurnal Gizi Indonesia. 33(1): 2028.

Azhari R, Mujiono P, Tjitropranoto P. 2013. Peran penyuluhan dalam peningkatan diversifikasi pangan rumah tangga. Jurnal Agro Ekonomi. 31(2): 181-198. https://doi.org/10.21082/ jae.v31n2.2013.181-198

[BSN] Badan Standardisasi Nasional. 1995. SNI 01-3951-1995 Susu Pasteurisasi. Jakarta.

Desa Jatinom. 2014. RPJM Desa tahun 2014 2019. Desa Jatinom. Kecamatan Kanigoro. Kabupaten Blitar.

Hakim L, Bintoro VP, Dwiloka B. 2017. Kandungan lemak, tekstur kemasiran dan kesukaan telur asin dengan penambahan jahe sebagai penyedap rasa. Jurnal Aplikasi Teknologi Pangan. 6(3): 199-124. https:// doi.org/10.17728/jatp.199

Hastuti S. 2010. Pengaruh perendaman dalam larutan kapur dan lama penyimpanan terhadap kualitas telur asin. Agroindustrial Teknologi. 4(1): 73-81.

Kustanti E. 2012. Otomatisasi proses mixing pada susu pasteurisasi. Malang (ID): Universitas Brawijaya.

Mu'addimah, Thohari I, Rosyidi D. 2015. Pengaruh konsentrasi sari kunyit putih
(Curcuma zediaria) terhadap kualitas telur asin ditinjau dari aktivitas antioksidan, total fenol, kadar protein, dan kadar garam. Jurnal Ilmu dan teknologi Hasil ternak. 10(1): 46-53. https://doi.org/10.21776/ub.jitek.2015.010. 01.6

Ranchman HPS, Ariani M. 2008. Penganekaragaman konsumsi pangan di Indonesia permasalahan dan implikasi untuk kebijakan dan program. Jurnal Analisis Kebijakan Pertanian. 6(2): 140-154.

Siahaan RF. 2017. Mengawal kesehatan keluarga melalui pemilihan dan pengolahan pangan yang tepat. Jurnal Keluarga Sehat Sejahtera. 15 (30): 57-64.

Sirait CH. 1984. Proses Pengolahan Susu Menjadi Yoghut. Jurnal Wartazoa. 1 (4): 5-8.

Sitepu A. 2016. Organisasi Sosial Lokal: Profil, Peran, dan Rekomendasi untuk Pembangunan Kesejahteraan Sosial. Jurnal Penelitian dan Pengembangan Usaha kesejahteraan Sosial. 11(2): 11-23.

Suharyanto. 2009. Pengolahan bahan pangan hasil ternak. Bengkulu (ID): Universitas Bengkulu.

Susanto WE, Kusumawati ED, Krisnaningsih ATN, Leondro H, Hadia DPP. 2018. Pelatihan dan pendampingan pengolahan susu afkir di Desa Kemantren Kecamatan Jabung. In: Conference on Innovation and Application of Science and Technology. Malang (ID): Universitas Widyagama, 12 September 2018.

Tantalu L, Sasongko P, Rozana. 2017. Peningkatan pendapatan anggota PP melalui usaha pembuatan yoghurt di Desa Wisata Mulyorejo Kecamatan Ngantang Kabupaten Malang. Jurnal Akses Pengabdian Masyarakat. 1(2): 18-22.

Winarti E. 2004. Laporan Kegiatan Penelitian dan Pengajian. Yogyakarta (ID): BPTP Yogyakarta. 